\title{
Determining the Knowledge Level of Parents about Their Children's Rational Drug Use
}

\author{
Ebeveynlerin Çocuklarının Akılcı İlaç Kullanımına İlişkin Bilgi Düzeylerinin Belirlenmesi
}

Department of Pediatric Dentistry, Faculty of Dentistry, Inonu University Malatya, Turkey

\section{Correspondence:}

Sacide DUMAN

Department of Pediatric Dentistry, Faculty of Dentistry, Inonu University, Malatya,Turkey e-mail: sacidetuncduman@gmail. com

\section{Abstract}

The main responsibility for the rational use of drugs (RUD) in children belongs to the parents. The aim of this study was to determine the knowledge and awareness level of parents about RUD in children. The study included literate volunteer parents with no learning disability. The rational drug use scale (RDUS), developed by Demirtas, was modified to assess parents' knowledge about RUD in children (higher score indicates higher knowledge level). Questionnaires for which all questions were not answered were excluded from the study. Two-group differences (gender, employment status, health insurance) were compared using the Mann-Whitney U test. Kruskal Wallis test was used to compare the differences among three or more groups (age: $\leq 30$, 30-40 and $>40$ years; education level: elementary, high school, associate degree and bachelor degree or higher; income: $<2000$ TL, 2000 $5000 \mathrm{TL}$ and $>5000 \mathrm{TL}$; number of children: $1,2,3$ and $\geq 4$ ). The study included 410 participants (mean age: $35 \pm 8.2$; female: $58.3 \%$ ). The mean scores obtained from the scale was $21.31 \pm 4.1$. Among females, the knowledge of RUD varied across education level $(\mathrm{X} 2=32.333, \mathrm{p}<0.001)$, income class $(\mathrm{X} 2=16.096, \mathrm{p}<0.001)$ and the number of children $(\mathrm{X} 2=7.868, \mathrm{p}=0.049)$. RDUS score was higher in employed females compared to non-employed females $(\mathrm{U}=2337.5, \mathrm{p}<0.001)$. In male participants, the knowledge of RUD varied across education level (X2=32.130, $\mathrm{p}<0.001)$, income class $(\mathrm{X} 2=16.893, \mathrm{p}<0.001)$ and the number of children $(\mathrm{X} 2=8.307$ $\mathrm{p}=0.040$ ). It was concluded that parents displayed incorrect attitudes and behavours regarding the use of drugs for in children.

Keywords: Children; parents; rational drug use scale; rational use of drugs.

\section{Özet}

Cocuklarda akılcı ilaç kullanmında (AİK) temel sorumluluk ebeveynlere aittir. Bu çalıșmanın amacı, ebeveynlerin çocuklarda AİK hakkında bilgi ve farkındalık düzeylerini belirlemektir. Çalışmaya okuryazar, öğrenme güçlüğü olmayan, gönüllü ebeveynler dahil edildi. Demirtaş tarafından geliștirilen akılcı ilaç kullanımı ölçeği (AİKÖ), ebeveynlerin çocuklarda AİK ile ilgili bilgilerini değerlendirmek üzere modifiye edildi (yüksek puan, yüksek bilgi düzeyini gösterir). Tüm soruları yanıtlanmayan anketler çalışma dışı bırakıldı.Ikki grup farklılıkları (cinsiyet, çalışma durumu, sağlık sigortası) Mann-Whitney U testi kullanılarak karşılaştırıldı. Üç ve daha fazla grup arasındaki farkllıkların karşılaştırılmasında Kruskal Wallis testi kullanıldı (yaş: $\leq 30,30-40$ ve $>40$ yıl; eğitim düzeyi: ilkokul, lise, önlisans ve lisans ve üzeri; gelir: $<2000 \mathrm{TL}, 2000-5000 \mathrm{TL}$ ve $>5000 \mathrm{TL}$; çocuk sayısı: $1,2,3$ ve $\geq 4$ ). Calıșmaya 410 kişi dahil edildi (ortalama yaş: $35 \pm 8.2$; kadın: \%58.3). Ölçekten alınan ortalama puan $21.31 \pm 4.1$ 'di. Kadın katılımcılarda AİK bilgisi, eğitim düzeyi $(\mathrm{X} 2=32.333, \mathrm{p}<0.001)$, gelir sınıfı $(\mathrm{X} 2=16.096, \mathrm{p}<0.001)$ ve cocuk sayısı $(\mathrm{X} 2=7.868, \mathrm{p}=0.049)$ parametrelerinde farklılık göstermiş̧tir. AİKÖ puanı çalışan kadınlarda çalışmayan kadınlara göre daha yüksekti ( $U=2337.5, p<0.001)$. Erkek katılımclarda AİK bilgisi eğitim düzeyine $(\mathrm{X} 2=32.130, \mathrm{p}<0.001)$, gelir sınıfına $(\mathrm{X} 2=16.893, \mathrm{p}<0.001)$ ve çocuk sayısına $(\mathrm{X} 2=8.307$, $\mathrm{p}=0.040$ ) göre değişiklik göstermiş̧tir. Ebeveynlerin çocuklarda ilaç kullanımı konusunda yanlış tutum ve davranışlar sergiledikleri sonucuna varılmıstıtr.

Anahtar Kelimeler: Çocuklar; ebeveynler; akılcı ilaç kullanım ölçeği; akılcı ilaç kullanımı.

Received 14.06.2021 Accepted 30.06.2021 Online published 01.07.2021 


\section{Introduction}

Irrational drug use is an important health problem that is difficult and time-consuming to correct (1). The irrational use of drugs may lead to a decrease in the compliance of the patient with the treatment, interaction between drugs, development of resistance to antibiotics, recurrence or prolongation of diseases and an increase in the incidence of side effects and treatment costs. Complications caused by irrational drug use constitute the basis for initiating studies on "Rational Use of Drugs (RUD)"(2). According to the World Health Organization (WHO), RUD requires that "patients receive medications appropriate to their clinical needs, in doses that meet their own individual requirements, for an adequate period of time, and at the lowest cost to them and their community" (1). RUD comprises the process from the production of the drug until the disposal of its waste. Decision-makers of the treatment to be applied in RUD, the users of drugs and the individuals who help them in their use of drugs, the science of pharmacology and its industry, the media, the health insurance system, and health authorities have important roles regarding RUD $(3,4)$.

The irrational use of drugs is major problem which affects health throughout the world (1, 2 ). These are common problems for patients who use medication without consulting their physician, advise other patients, act according to the recommendations of non-medical personnel or use home remedies when symptoms similar to a previous disease occur (1-6). According to studies conducted in Turkey, analgesics are the leading drugs that are purchased without a prescription and consulting a physician due to their affordable prices and ease of access $(3,5,6)$. A "prescription tracking system" has been developed by the Turkish Ministry of Health to prevent drug intake without prescription and unnecessary intake of drugs such as antibiotics, which may also be applicable in the field of dentistry. Although this reduces the rate of development of this problem, the irrational use of drugs continues. Moreover, the unnecessary use of analgesics and antibiotics may cause serious side effects, especially in paediatric patients and patients with kidney and liver dysfunction $(3,7)$.

Parents are responsible for both themselves and their children concerning RUD, and they have great responsibility in the community regarding the use of drugs $(7,8)$. Although there is no scale developed to measure RUD awareness of parents regarding the use of drugs by children Turkey or other countries and abroad, various measurement tools developed for similar purposes have been found $(4-6,9-15)$. The aim of this study was to determine the knowledge and awareness level of parents about RUD in children.

\section{Methods}

This study is a cross-sectional study involving participants brought their children to the Faculty of Dentistry between September and December 2020. Required permissions and approvals for this study were obtained from the Ethics Committee of the university (2020/1152). Additionally, the parents were informed about the purpose of the study, and their consent was obtained.

\section{Study Design and Sample Selection}

The parents, who presented to the Department of Pediatric Dentistry at a public university for their children, were determined as the population of the study. The total number of the patients who visited the department in the first 9 months of 2020 was determined as 7800. It was estimated that the total number of the patients admitted by the end of the year would be around $\mathrm{N}=10.000$. In this crosssectional study, using the simple random sampling method, it was calculated that at least $\mathrm{n}=370$ participants with a $5 \%$ acceptable margin of error and in a $95 \%$ confidence interval could provide the representation power of the population. It was determined that 370 parents to be included in the sample would provide a sampling power of 0.95 (values of 0.70 and above are predicted to be valid and sufficient in similar studies), with an effect size of 0.35 ( 0.10 for small, 0.25 for medium and 0.40 for large effect size). In this study, the calculations of the population-sample, power level and effect 
size were performed on $G^{*}$ Power Version 3.1.7.

\section{Data Collection}

The demographic information (e.g., age, gender, education level, level of income) of the participants was recorded. The study included literate volunteering parents with no learning disability. Questionnaires for which all questions were not answered were excluded from the study.

In this study, the knowledge of the parents about RUD was evaluated using the Rational Drug Use Scale (RDUS), which was developed and tested for validity and reliability by Demirtas et al. (9) (2018). RDUS was designed for adults. In this study, to determine the attitudes and knowledge levels of the parents regarding RUD in their children, the scale was administered as a scale of 19 items including 10 "correct" and 9 " incorrect" statements (Q). Each statement was asked to be evaluated as "correct", "incorrect" or "no idea". The "correct" answer was scored 2 points, the "incorrect" answer was scored as 0 points, and the "no idea"

answers were scored 1 point (26-0). It was accepted that the knowledge level of the participant increased as their score in the scale increased. Based on the questions determined by Aktas and Selvi (10) in RDUS studies, the participants' RUD knowledge was questioned, and a cut-off point was determined. The participants above the cut-off point were defined as rational drug users. The scores that could be obtained from the scale ranged from 0 to 26. The phrase "your child" was added to the original scale (9), two questions that were not related to children were removed, and thus, the scale was modified.

\section{Statistical Analysis}

\section{Statistical Tests}

Data analysis was performed using SPSS 25 software and studied with $95 \%$ confidence interval. The categorical variables are presented as frequency and percentage (n; \%); the numerical variables are presented as median, minimum and maximum (min-max), mean (M) and standard deviation. According to the rational drug use behaviour, the cut-off point of the scale was calculated by ROC analysis.

In the study, the difference in the RDUS scores of the participants based on their demographic characteristics was analysed with Mann-Whitney $U$ and Kruskal Wallis tests. In addition, in comparisons with $\mathrm{k}(\mathrm{k}>$ 2) groups, Bonferroni correction was used for the intragroup comparisons. Since there were two items removed from the original structure of RDUS, exploratory factor analysis (EFA) was carried out to determine the construct validity of the scale, and Cronbach's alpha reliability coefficients were calculated to determine its reliability. $\mathrm{P}<0.05$ were considered significant.

\section{Test of Normality}

Shapiro Wilk test was used to determine the normality of the distribution of the RDUS scores of the participants. According to the test results, it was determined that the RDUS scores did not show normal distribution in the female $(0.908 ; \mathrm{p}<0.05)$ and the male $(0.887$; $\mathrm{p}<0.05)$. Accordingly, nonparametric test techniques were used in the analysis.

\section{Results}

The distribution of the demographic characteristics of the participants is presented in Table 1. This study included 410 participants (female: $58.3 \%, \mathrm{n}=239$; male: $41.7 \% \mathrm{n}=171$ ). Among the participants who responded to the questionnaire, $57.3 \%(\mathrm{n}=$ 235) were between 31 and 40 years of age, $38.5 \%(\mathrm{n}=158)$ had primary school degrees, $57.6 \%(n=236)$ had a level of income between 2000 and 5000 TL per month, $56.6 \%(\mathrm{n}=232)$ were unemployed, $90.2 \%(\mathrm{n}=370)$ had health insurance, and $42.2 \%(n=173)$ had 2 children. 
Table 1. The distribution of demographic features.

\begin{tabular}{|c|c|c|}
\hline & & $\begin{array}{r}\text { Total } \\
\text { n (\%) }\end{array}$ \\
\hline \multirow{2}{*}{ Gender } & Female & $239(58.3)$ \\
\hline & Male & $171(41.7)$ \\
\hline \multirow[t]{3}{*}{ Age } & $\leq 30$ & $57(13.9)$ \\
\hline & $31-40$ & $235(57.3)$ \\
\hline & $>40$ & $118(28.8)$ \\
\hline \multirow[t]{4}{*}{ Education status } & Elementary & $158(38.5)$ \\
\hline & High & $127(31)$ \\
\hline & Associate degree (two years) & $39(9.5)$ \\
\hline & $\geq$ Bachelor degree & $86(21)$ \\
\hline \multirow[t]{3}{*}{ Income status } & $<2000 \mathrm{TL}$ & $99(24.1)$ \\
\hline & $2000-5000 \mathrm{TL}$ & $236(57.6)$ \\
\hline & $>5000 \mathrm{TL}$ & $75(18.3)$ \\
\hline \multirow[t]{2}{*}{ Employment status } & Yes & $178(43.4)$ \\
\hline & No & $232(56.6)$ \\
\hline \multirow[t]{2}{*}{ Health insurance } & Yes & $370(90.2)$ \\
\hline & No & $40(9.8)$ \\
\hline \multirow[t]{4}{*}{ Number of children } & 1 & $36(8.8)$ \\
\hline & 2 & $173(42.2)$ \\
\hline & 3 & $128(31.2)$ \\
\hline & $\geq 4$ & $73(17.8)$ \\
\hline
\end{tabular}

\section{Construct Validity and Reliability Analysis}

According to the analysis results, the KaiserMeyer Olkin (KMO) value of RDUS (0.772) was higher than 0.500 , and its Bartlett's X2 test result was found to be significant $(\mathrm{X} 2=$ 1195.99; $\mathrm{p}<0.05)$. Accordingly, the scale was suitable for factor analysis.

Items $1,3,7,9,14$ and 19 were excluded from the analysis due to their low factor load values (smaller than 0.300) according to the results of the EFA. The final factor distribution is given in Table 2.

The scale consisted of 13 items with factor loadings ranging from 0.702 to 0.312 . The rate of the total variance explained by the factors was $26.927 \%$, and the reliability level of the scale was found to be high (0.752).

Table 2. Factor loadings and correct answer percentages of rational drug use scale items.

\begin{tabular}{|c|c|c|c|c|c|}
\hline Item & & $\begin{array}{c}\text { Correct } \\
\text { answer } \\
\text { percentages }\end{array}$ & $\begin{array}{l}\text { Factor } \\
\text { loading }\end{array}$ & $\begin{array}{c}\text { Explained } \\
\text { Variance Ratio }\end{array}$ & $\begin{array}{l}\text { Cronbach's } \\
\text { Alpha }\end{array}$ \\
\hline Q15 & The treatment time for each drug is equal. & 79.0 & 0.702 & \multirow{10}{*}{26.927} & \multirow{10}{*}{0.752} \\
\hline Q10 & $\begin{array}{l}\text { Consuming herbal products as much as desired does not harm my } \\
\text { child's health. }\end{array}$ & 55.1 & 0.634 & & \\
\hline Q18 & Expensive drugs are more effective for my child. & 79.5 & 0.630 & & \\
\hline Q5 & All medicines produce the same side effects. & 77.2 & 0.603 & & \\
\hline Q16 & Herbal products are completely harmless to my child. & 56.1 & 0.589 & & \\
\hline Q13 & $\begin{array}{l}\text { When my child feels well during the treatment, we can stop using } \\
\text { the medication. }\end{array}$ & 59.5 & 0.577 & & \\
\hline Q2 & $\begin{array}{l}\text { We can recommend medication to the children of our relatives } \\
\text { who have similar complaints. }\end{array}$ & 85.4 & 0.522 & & \\
\hline Q6 & $\begin{array}{c}\text { It is not harmful for my child to take the medication frequently at } \\
\text { intervals indicated by the doctor. }\end{array}$ & 55.6 & 0.521 & & \\
\hline Q12 & $\begin{array}{l}\text { While the doctor arranges the treatment, I inform the doctor of } \\
\text { the medications that my child is still using. }\end{array}$ & 89.0 & 0.432 & & \\
\hline Q11 & I consult the doctor when I see an undesirable effect on my child & 97.3 & 0.356 & & \\
\hline
\end{tabular}




\begin{tabular}{|cccc}
\hline Q8 & $\begin{array}{c}\text { while taking medication. } \\
\text { Failure to use the medicine for the period indicated by the doctor } \\
\text { may prevent my child from recovering. }\end{array}$ & 72.2 & 0.324 \\
\hline Q17 & $\begin{array}{c}\text { My child's use of a sufficient number of drugs, not a large } \\
\text { number of drugs, provides recovery. }\end{array}$ & 85.9 & 0.323 \\
\hline Q4 & Medications can have negative effects as well as positive effects. & 92.7 & 0.312 \\
\hline
\end{tabular}

\section{Evaluation of RDUS}

In the sample of the study, the mean $( \pm$ standard deviation) score in the scale was $21.31( \pm 4.1)$, the extreme values were between 7.0 and 26.0, and the cut-off point was determined as 22 . It was found that $59 \%$ $(n=242)$ of the participants displayed rational drug use behaviour (RDUS score $\geq 22$ ) while using drugs for their children. There was no statistically significant difference between the male and female participants in terms of their levels of knowledge about RUD for their children $(\mathrm{p}>0.05)$ (Table 3$)$.

Table 3. Comparison of rational use of drugs information according to gender.

\begin{tabular}{|c|c|c|c|c|c|}
\hline & & Min-Max (Median) & Mean \pm SD & $\mathbf{U}$ & p \\
\hline \multirow[t]{2}{*}{ Gender } & Female & $7-26(22)$ & $21.51 \pm 3.99$ & \multirow{2}{*}{19598.5} & \multirow{2}{*}{0.477} \\
\hline & Male & $10-26(22)$ & $21.12 \pm 4.35$ & & \\
\hline
\end{tabular}

Min-Max; Minimum-Maximum, U; Mann-Whitney U test, $p>0.05$; No significant difference.

Among the female participants, the knowledge of RUD for their children varied based on their education levels $(\mathrm{X} 2=32.333$, $\mathrm{p}<0.001)$, levels of income $(\mathrm{X} 2=16.096$, $\mathrm{p}<0.001)$, employment status $(\mathrm{U}=2337.5$, $\mathrm{p}<0.001)$ and the numbers of their children $(\mathrm{X} 2=7.868, \mathrm{p}=0.049)$. While the level of knowledge about RUD was the highest among the participants with associate degrees $(23.13 \pm 3.04)$ and higher education degrees (23.98 \pm 2.26$)$, it was the lowest among the participants with primary school degrees (20.4 \pm 3.84$)$. While the level of knowledge about RUD was the highest among the participants with a level of income above 5000 TL $(23.08 \pm 4.21)$, it was the lowest among the participants with a level of income below 2000 TL (20.45 \pm 4.04$)$. The employed participants had a higher level of knowledge about RUD (23.32 \pm 3.88$)$. While the level of knowledge about RUD was the highest among the participants with a single child $(23 \pm 3.24)$, it was the lowest among the participants with more than 3 children $(20 \pm 4.89)$ (Table 4). Among the male participants, the knowledge of RUD varied based on their education levels $(\mathrm{X} 2=32.130, \mathrm{p}<0.001)$, levels of income $(\mathrm{X} 2=16.893, \mathrm{p}<0.001)$ and the numbers of their children $(X 2=8.307, \mathrm{p}=0.040)$. While the level of knowledge about RUD was the highest among the participants with associate degrees $(23.21 \pm 2.34)$ and higher education degrees (22.93 \pm 4.2$)$, it was the lowest among the participants with primary school degrees (18.82 \pm 4.22$)$. While the level of knowledge about RUD was the highest among the participants with a level of income above 5000 TL (22.54 \pm 3.97$)$, it was the lowest among the participants with a level of income below 2000 TL $(18.81 \pm 4)$. Moreover, the level of knowledge about RUD was the highest among the participants with a single child (23 \pm 3.35$)$ (Table 4). 
Table 4. Comparison of rational use of drugs information according to demographic features.

\begin{tabular}{|c|c|c|c|c|c|c|c|c|c|}
\hline & & & Female & & Test & & Male & & Test \\
\hline & & n (\%) & $\begin{array}{l}\text { Min-Max } \\
\text { (Median) }\end{array}$ & Mean \pm SD & \multirow{4}{*}{$\begin{array}{c}\mathrm{X}^{2}=0.374 \\
\mathrm{p}=0.830\end{array}$} & n $(\%)$ & $\begin{array}{l}\text { Min-Max } \\
\text { (Median) }\end{array}$ & Mean \pm SD & \multirow{4}{*}{$\begin{array}{c}X^{2}=0.539 \\
p=0.764\end{array}$} \\
\hline \multirow[t]{3}{*}{ Age } & $\leq 30$ & $42(17.6)$ & $\begin{array}{c}11- \\
26(22.5)\end{array}$ & $21.33 \pm 4.1$ & & $15(8.8)$ & $16-25(22)$ & $21.07 \pm 2.99$ & \\
\hline & $31-40$ & $145(60.7)$ & $7-26(22)$ & $21.41 \pm 4.12$ & & $90(52.6)$ & $10-26(22)$ & $21.21 \pm 4.2$ & \\
\hline & $>40$ & $52(21.8)$ & $\begin{array}{c}14- \\
26(22.5)\end{array}$ & $21.9 \pm 3.56$ & & $66(38.6)$ & $10-26(23)$ & $21.02 \pm 4.82$ & \\
\hline \multirow{4}{*}{$\begin{array}{l}\text { Education } \\
\text { status }\end{array}$} & Elementary & $113(47.3)$ & $11-26(20)$ & $20.4 \pm 3.84$ & \multirow{2}{*}{$\begin{array}{c}\mathrm{X}^{2}=32.333 \\
\mathrm{p}<0.001^{*}\end{array}$} & $45(26.3)$ & $10-26(19)$ & $18.82 \pm 4.22$ & \multirow{2}{*}{$\begin{array}{l}X^{2}=32.130 \\
p<0.001 *\end{array}$} \\
\hline & High & $67(28)$ & $7-26(22)$ & $21.39 \pm 4.51$ & & $60(35.1)$ & $10-26(22)$ & $20.75 \pm 4.3$ & \\
\hline & $\begin{array}{l}\text { Associate } \\
\text { degree }\end{array}$ & $15(6.3)$ & $14-26(24)$ & $23.13 \pm 3.04$ & & $24(14)$ & $17-26(24)$ & $23.21 \pm 2.34$ & \multirow{5}{*}{$\begin{array}{c}X^{2}=16.893 \\
p<0.001 *\end{array}$} \\
\hline & $\begin{array}{l}\geq \text { Bachelor } \\
\text { degree }\end{array}$ & $44(18.4)$ & $17-26(24)$ & $23.98 \pm 2.26$ & & $42(24.6)$ & $10-26(24)$ & $22.93 \pm 4.2$ & \\
\hline \multirow{3}{*}{$\begin{array}{l}\text { Income } \\
\text { status }\end{array}$} & $<2000 \mathrm{TL}$ & $67(28)$ & $9-26(20)$ & $20.45 \pm 4.04$ & \multirow{3}{*}{$\begin{array}{c}X^{2}=16.096 \\
p<0.001^{*}\end{array}$} & $32(18.7)$ & $10-24(19)$ & $18.81 \pm 4$ & \\
\hline & $\begin{array}{l}2000-5000 \\
\text { TL }\end{array}$ & $132(55.2)$ & $10-26(22)$ & $21.57 \pm 3.76$ & & 104(60.8) & $10-26(22)$ & $21.36 \pm 4.33$ & \\
\hline & $>5000 \mathrm{TL}$ & $40(16.7)$ & $7-26(24)$ & $23.08 \pm 4.21$ & & $35(20.5)$ & $10-26(24)$ & $22.54 \pm 3.97$ & \\
\hline \multirow{2}{*}{$\begin{array}{l}\text { Employment } \\
\text { status }\end{array}$} & Yes & $37(15.5)$ & $7-26(24)$ & $23.32 \pm 3.88$ & \multirow{2}{*}{$\begin{array}{l}U=2337.5 \\
p<0.001^{*}\end{array}$} & 141(82.5) & $10-26(22)$ & $21.23 \pm 4.42$ & \multirow{2}{*}{$\begin{array}{c}U=1827.0 \\
p=0.239\end{array}$} \\
\hline & No & $202(84.5)$ & $9-26(22)$ & $21.17 \pm 3.93$ & & $30(17.5)$ & $10-26(21)$ & $20.6 \pm 4.01$ & \\
\hline \multirow{2}{*}{$\begin{array}{l}\text { Health } \\
\text { insurance }\end{array}$} & Yes & 212(88.7) & $26-7(22)$ & $21.52 \pm 4$ & \multirow{2}{*}{$\begin{array}{c}U=2786.5 \\
p=0.822\end{array}$} & $158(92.4)$ & $10-26(22)$ & $21.12 \pm 4.44$ & \multirow{2}{*}{$\begin{array}{l}U=920.5 \\
p=0.239\end{array}$} \\
\hline & No & $27(11.3)$ & $12-26(22)$ & $21.41 \pm 3.98$ & & $13(7.6)$ & $13-24(22)$ & $21.15 \pm 3.13$ & \\
\hline \multirow{4}{*}{$\begin{array}{l}\text { Number of } \\
\text { children }\end{array}$} & 1 & $25(10.5)$ & $14-26(24)$ & $23 \pm 3.24$ & \multirow{4}{*}{$\begin{array}{l}X^{2}=7.868 \\
p=0.049 *\end{array}$} & $11(6.4)$ & $15-26(24)$ & $23 \pm 3.35$ & \multirow{4}{*}{$\begin{array}{l}X^{2}=8.307 \\
p=0.040 *\end{array}$} \\
\hline & 2 & $100(41.8)$ & $11-26(23)$ & $21.84 \pm 3.64$ & & $73(42.7)$ & $10-26(23)$ & $21.52 \pm 4.3$ & \\
\hline & 3 & $72(30.1)$ & $9-26(22)$ & $21.4 \pm 3.91$ & & $56(32.7)$ & $10-26(20)$ & $20 \pm 4.41$ & \\
\hline & $\geq 4$ & $42(17.6)$ & $7-26(20)$ & $20 \pm 4.89$ & & $31(18.1)$ & $12-26(23)$ & $21.55 \pm 4.36$ & \\
\hline
\end{tabular}

\section{Discussion}

In this study, it was aimed to investigate the level of knowledge and awareness of parents, who are responsible for the use of drugs in their children. The currently available questionnaires may not present results suitable for use regarding RUD because they are weak in terms of measurement power and causeeffect relationships. It is necessary to use a standardized measurement instrument that represents the developed population and provides a total score (10). The factor loads of the items of the scale that was used with modification in this study showed whether

they measured the related concept or construct accurately in the factor analysis. KMO and Bartlett's tests are performed primarily to determine whether the analysed scale is suitable for factor analysis. The KMO test measurement result should be 0.50 and higher, and the Bartlett's test result should be statistically significant. In this study, the KMO value of RDUS (0.772) was higher than 0.500 , and its Bartlett's test result was found to be significant $(\mathrm{p}<0.05)(16)$. Accordingly, the scale was suitable for factor analysis. 
Additionally, 6 items with a factor load value of $<0.30$ (17) were excluded from the scale.

This study qualifies as a first since the questions, which were included in the RDUS developed by Demirtas et al. (9) to measure levels of knowledge in adult patients regarding RUD, were used after they were modified with the aim of determining the attitudes of parents about drug treatment in paediatric patients. The Cronbach's alpha coefficient representing internal consistency is desired to be above 0.70 for a reliable scale (18). Since the Cronbach's alpha coefficient of the scale was calculated as 0.752 (explained variance rate: $26.927 \%$ ), in this study, this scale remained compatible with the original scale after some items were removed, and some were added.

When the level of knowledge regarding RUD was evaluated according to the demographic data, it was found that the level of knowledge increased in the participants as their levels of education and income increased. In this regard, this study was similar to other studies in this field $(9,15)$. However, it differed from other studies in that this study did not identify a statistically significant difference in their levels of knowledge about RUD based on the participants' gender and age $(9,15)$. It was also determined that, among all participants, increased numbers of children affected the participants' levels of knowledge about RUD negatively.

All healthcare professionals, especially physicians, play an important role in promoting the rational and appropriate use of drugs. Many previous studies have suggested that the training to be provided to physicians and dentists on RUD would play a key role (19-21). Nonetheless, healthcare professionals, who are required to fulfil the responsibility of providing information about RUD, do not have the desired level of interest (12). In the study by Serce and Bakır (22) on this topic, it was reported that physicians had sufficient knowledge about RUD; however, they could prescribe unnecessary drugs as they could allocate less time to patients and as they had to deal with patients constantly due to their intense workload. Additionally, in a study conducted with the aim of determining the factors affecting the rational drug use of the patients of physicians, it was determined that $77 \%$ of the participating physicians did not provide information about the drugs they prescribed to their patients (23). In another study, $69 \%$ of physicians were found to provide information about how to use the drug, and $14.4 \%$ provided information about the side effects of the drug (24). Individuals who are insufficiently informed about RUD by healthcare professionals try to satisfy their hunger for information by reading the medication package insert (12). However, since the information in the medication package insert is mostly written in medical language, and there may be differences in the literacy skills of individuals living in each region, what is written in the medication package insert might not be understood by the patient or their legal guardians. In this study, the rate of the participants who showed rational drug use behaviour while using drugs for their children was only $59 \%$. This may be attributed to the fact that the majority of the participants had high school degrees at most, the majority were non-employed female participants, and healthcare professionals in Turkey were unable to fulfil their responsibility to provide sufficient information due to their workload.

This study had some limitations. First of all, information on the drug use habits and behaviours of the participating individuals was obtained through the participants' own reports. When the current literature was reviewed, it was determined that studies conducted outside Turkey mostly included the rational use of antibiotics, and there were few studies on general drug use habits. Additionally, RDUS is a scale in Turkish, and there are no studies conducted in different countries using this scale yet. This situation created a limitation in discussing the results of this study alongside studies conducted in different countries.

It was concluded that parents displayed incorrect attitudes and behavours regarding the use of drugs for their children. The reasons for the families' lack of knowledge about RUD should be investigated in more detail and eliminated. Parents need to be informed about the aim of RUD using 
appropriate communication channel. In this context, multi-directional, long-term, wellplanned, which use appropriate tools to reach the target group in cooperation with experts, healthcare professionals, and civil society organizations are required.

\section{Acknowledgements}

The authors wish to thank all participants for their invaluable contribution to this study

\section{REFERENCES}

1. World Health Organization. The rational use of drugs: Report of the Conference of Experts Nairobi 25-29 November; 1985.

2. World Health Organization. Promoting Rational use of Medicines: Core Components. WHO Policy Perspectives on Medicines. Report WHO/EDM/2002.3. Geneva: WHO; 2002.

3. Yapıc1 G, Balıkcı S, Ugur O. Attitudes and behavior of drug usage in applicants to primary health care center. Dicle Med J. 2011;38:458-465.

4. Yılmaz M, Kırbiyıkoglu FI, Aric Z, et al. Determination of rational drug use by patients at a dentistry faculty hospital. ERU Saglik Bilimleri Fak Derg. 2014;2: 39-47.

5. Karakurt P, Hacıhasanoglu R, Yıldırım A,et al. Medication Use among University Students. TAF Prev Med Bull. 2010; 9: 505-512.

6. Beggi B, Asık Z. Evaluation of Rational Drug Use in Patients Applying to Family Medicine Outpatient Clinic. Ankara Med J. 2019;19:25160.

7. Republic of Turkey Social Security Institution Rational Use of Drugs for Society. http://www.akilciilac.gov.tr. Accessed November 21, 2012.

8. Canoglu E, Gungor HC, Bozkurt A. Medicine usage in pediatric dentistry. $J$ Hacettepe Faculty Dentistr. 2009; 33: 30-44.

9. Demirtas Z, Dagtekin G, Saglan R, et al. Validity and reliability of rational drug use scale. ESTUDAM Public Health Journal. 2018; 3:37-46.

10. Aktas H, Selvi H. Erişkinlerde akılcı ilaç kullanımı farkındalık ölçeğinin geliştirilmesi: Geçerlik ve güvenirlik çalışması. Mersin Univ Saglık Bilim Derg. 2019;12:439-447

11. Ekici MA, Kurutcu S, Uysal B. Measurement of rational drug use knowledge level in adults. JSHSR. 2019;6:179-189.

12. Yılmaz M, Güler N, Güler $G$, et al. Some behaviors a group of the womens related drug use: Is it rational? CMJ. 2011;33: 266-277.

13. Padley SD, Chaudhari VL. Impact of public education on rational use of medicines. Int $J \mathrm{Med}$ Sci Public Health. 2017;6:245-249.

14. Nutt D, King LA, Saulsbury $W$, et al. Development of a rational scale to assess the harm of drugs of potentia 1 misuse. Lancet. 2007;369:1047-1053.

15. Bian $\mathrm{C}, \mathrm{Xu} \mathrm{S}$, Wang $\mathrm{H}$, et al. A study on the application of the information-motivationbehavioral skills (IMB) model on rational drug use behavior among second-level hospital outpatients in Anhui, China. Plos One. 2015;10:e135782.

16. Cokluk O, Sekercioglu G, Buyukozturk S. Sosyal bilimler için çok değişkenli istatistik: SPSS ve LISREL uygulamaları. 2018, Pegem Akademi, Ankara.

17. Harrington D. Confirmatory factor analysis. 2009. Oxford University Press, Newyork USA.

18. Malinowska KS, Kaczmarek U, Zietek M, et al. Validation of the Polish version of the oral health impact profile-14. Adv Clin Exp Med. 2015;24:129-137.

19. Patel V, Vaidya R, Naik D, et al. Irrational drug use in India: a prescription survey from Goa. $J$ Postgrad Med. 2005: 51: 9-12

20. Salako NO, Rotimi VO, Adib SM, et al. Patterns of antibiotic prescription in the management of oral diseases among dentists in Kuwait. J Dent. 2004: 32: 503-509

21. Palmer NAO, Pealing R, Ireland RS, et al.A study of therapeutic antibiotic prescribing in national health service general dental pratice in England. Br Dent J. 2000: 188: 554-558.

22. Serce O, Bakır M. Longer time spent for patient in outpatient setting is associated with lower antibiotic prescription. The Journal of Current Pediatrics. 2013; 11: 45-50.

23. Akıcı A, Kalaca S, Ugurlu MU, et al. Evaluation of rational drug use of general practitioners' in management of elderly patients. Turkish Journal of Geriatrics. 2001; 4: 100-105.

24. Ozata M, Aslan S, Mete M. Effects of rational drug use on patient safety: Determining the factors affecting physicians' rational drug use. SUSBED. 2008; 20:529-542. 